\title{
THE LOCAL INCIDENCE OF THE DECLINE IN THE BIRTH-RATE, 1876-1898.
}

\author{
BY HENRY MAY, L.R.C.P., \\ Late Medical Officer of Health of Aston Manor.
}

The decline in the birth-rate in England and Wales, and other European countries, peculiar to the last twenty-two years, has been already the subject of consideration in Public Health, and its relation to the marriage-rate has been demonstrated graphically. It seems to me a somewhat superficial way of dealing with this important social departure to be content with merely taking into consideration the birth-rate of the country as a whole, made up as it is of the rates of widely-varying districts with diverse local conditions-agricultural, manufacturing, and industrial. In order to properly appreciate the decline, it is desirable to ascertain what has been the comparative share of town and country in bringing it about, and how far different localities have contributed towards it. It is not surprising that there has been a considerable fall in the rural districts, owing to the migration from them of young and marriageable persons into the towns, which has been going on to such an extent for many years as to have become almost a national calamity; but it will be found on analysis that the decline in these districts, with one or two exceptions, has been but moderate. At the same time, it must be remembered the birth and marriage rates have always been less in country distriets than in towns, though the marriage-rates in most rural counties have now recovered from their depression, which is not the case in industrial ones, with the exception of Warwickshire.

So far from finding, as one would have expected, that the decline has been greatest in rural districts from which the young have emigrated, and that some compensation is to be found in towns and suburban districts, it is in those very places into which this centripetal migration has been most active that the fall in the birth-rate is most marked, and where the lowest rates have been reached, and any rise they show in population is more from immigration than from their natural increase.

The average birth-rate of this country continues to fall, viz., from $29 \cdot 7$ in 1896 and 1897 to 29.4 in 1898 , in the face of the increasing appreciation of marriage, and in spite of the greatly altered ageconstitution of the population, for the increased proportion of persons now living at marriageable and child-bearing ages ought 
naturally to be accompanied with a higher birth-rate. It is desirable to arrive at the amount of the decline for the whole country to be able to judge the relative as well as the actual extent of the fall in different localities. I have reason to think my first estimate of 15 per cent. for this was too low, and that it is nearly 20 per cent. It seemed scarcely fair to take the difference between the highest recorded birth-rate-viz., $36 \cdot 3$ in 1876-and the present one-29.7-as the measure of the fall; but, according to Dr. Farr, the high rate of 1876 should not be considered as an exceptional one up to that date, for the Act which made the registration of births compulsory was passed in 1875. He estimates that an average of 5 per cent. had previously escaped registration, and that the rate of 1876 should be taken as the average for previous years. The decline since then is equal to a rate of 6.9 per 1,000 of the population, and this represents an annual loss upon a population of $30,000,000$ of 200,000 births. It amounts to a total decline of 18 per cent. in twenty-two years, and how far different counties and towns have relatively contributed to make up the average total will be seen from the following tables:-

Birth-rates of different Counties of England and Wales in the years 1876 and 1897, showing the total decline and decline per cent. during the interval.

\begin{tabular}{|c|c|c|c|c|c|}
\hline & & \multicolumn{2}{|c|}{ BIRTH-RATE. } & \multicolumn{2}{|c|}{ DECLINE. } \\
\hline & & 1876. & 1897. & Actual. & Per cent. \\
\hline \multirow{2}{*}{\multicolumn{2}{|c|}{$\begin{array}{l}\text { England and Wales } \ldots \\
\text { Counties with high birth-rates: }\end{array}$}} & $36 \cdot 3$ & $29 \cdot 7$ & 66 & $18 \cdot 0$ \\
\hline & & & & & \\
\hline Durham $\ldots \quad \ldots$ & $\ldots$ & $45 \cdot 2$ & $35 \cdot 2$ & 100 & $22 \cdot 1$ \\
\hline Staffordshire & $\ldots$ & $43 \cdot 5$ & $34 \cdot 6$ & $8 \cdot 9$ & $20 \cdot 5$ \\
\hline Derbyshire $\quad \ldots$ & $\ldots$ & $41 \cdot 7$ & $31 \cdot 3$ & $10 \cdot 4$ & $24 \cdot 9$ \\
\hline Nottinghamshire ... & $\ldots$ & 416 & $32 \cdot 2$ & $9 \cdot 4$ & $20 \cdot 1$ \\
\hline Lancashire $\quad \ldots$ & $\ldots$ & $41 \cdot 2$ & $31 \cdot 1$ & $10 \cdot 1$ & $24 \cdot 5$ \\
\hline Northumberland ... & $\ldots$ & $40 \cdot 6$ & $32 \cdot 5$ & $8 \cdot 1$ & $20 \cdot 0$ \\
\hline Leicester $\ldots . \quad \ldots$ & $\ldots$ & $40 \cdot 1$ & $30 \cdot 8$ & $9 \cdot 3$ & $23 \cdot 2$ \\
\hline West Riding & $\ldots$ & $39 \cdot 6$ & $30 \cdot 3$ & $9 \cdot 3$ & $23 \cdot 5$ \\
\hline Warwickshire ... & $\ldots$ & $39 \cdot 3$ & $32 \cdot 6$ & $6 \cdot 7$ & $17 \cdot 0$ \\
\hline \multicolumn{2}{|c|}{ Counties with low birth-rates: } & & & & \\
\hline Wiltshire $\ldots \quad \ldots$ & $\ldots$ & $30 \cdot 9$ & $25 \cdot 7$ & $5 \cdot 2$ & $16 \cdot 8$ \\
\hline Hampshire & $\ldots$ & $30 \cdot 8$ & $26 \cdot 3$ & $4 \cdot 5$ & $11 \cdot 4$ \\
\hline Westmorland & $\ldots$ & $30 \cdot 4$ & $22 \cdot 6$ & $7 \cdot 8$ & $25 \cdot 6$ \\
\hline $\begin{array}{lll}\text { Sussex } & \ldots & \ldots\end{array}$ & $\ldots$ & $30 \cdot 2$ & $23 \cdot 2$ & 70 & $23 \cdot 3$ \\
\hline Surrey (extra Met.) & $\ldots$ & $30 \cdot 1$ & $24 \cdot 6$ & 5.5 & $18 \cdot 0$ \\
\hline Devonshire $\quad \ldots$ & $\ldots$ & $29 \cdot 2$ & $25 \cdot 3$ & $3 \cdot 9$ & $13 \cdot 3$ \\
\hline Dorsetshire & $\ldots$ & $28 \cdot 5$ & $25 \cdot 6$ & $2 \cdot 9$ & 100 \\
\hline Cornwall ... & $\ldots$ & $28 \cdot 4$ & $25 \cdot 4$ & $3 \cdot 0$ & 105 \\
\hline Herefordshire & $\ldots$ & $28 \cdot 2$ & 26.9 & $1 \cdot 3$ & $4 \cdot 6$ \\
\hline
\end{tabular}


Birth-rates in different Large Towns of England and Wales in the years 1876 and 1898, showing the total decline and decline per cent. during the interval.

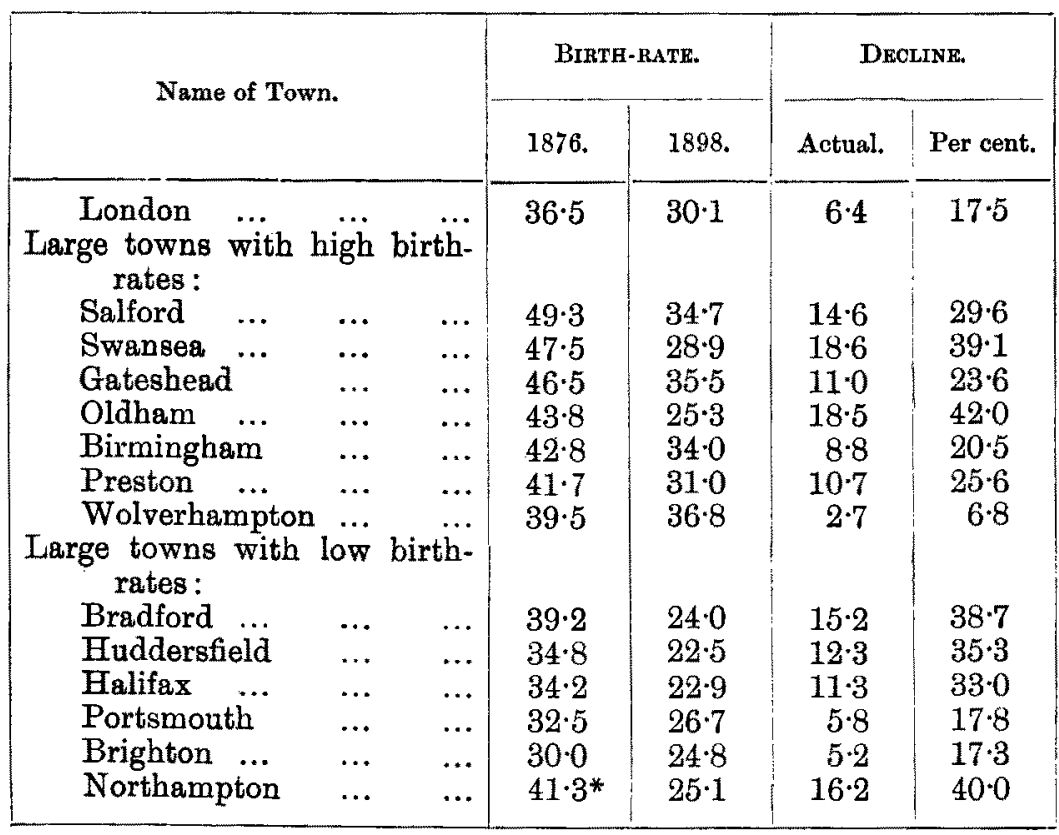

There is no place without some decline, and none except Herefordshire where it is not considerable. It has been much greater proportionately in manufacturing and industrial counties like Lancashire and Yorkshire, and large manufacturing towns like Swansea and Bradford, than in the agricultural counties. In Oldham and Northampton it has been about 40 per cent. One is not surprised, considering its history, that the latter should show a very great decline in births, and its medical officer gives an excellent chart of the birth-fall there in his last annual report. Wolverhampton has at present the highest birth-rate of all the large towns.

The conditions of life in Scotland are so nearly similar to those in England and Wales that it will be instructive to examine a table showing the proportionate extent of the decline in different localities in that part of the kingdom. The fall dates from the same year -1876; but it appears to have terminated in 1894. 
Birth-rates in different Localities of Scotland in the years 1876 and 1894, showing the amount of the decline in the Birth-rate during the interval of eighteen years.

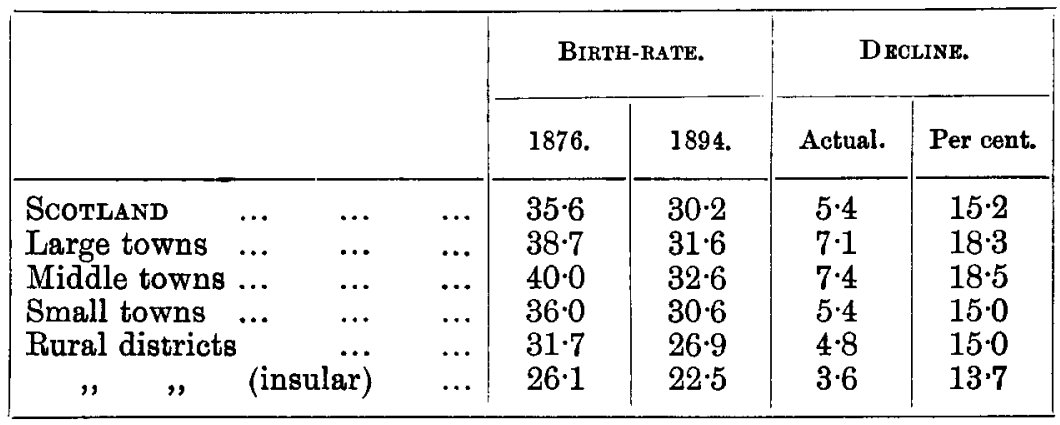

The conditions of life in Ireland, with its low marriage-rate of $8 \cdot 10$ per 1,000 , and its decreasing population through emigration, are not such as to give any comparative value to particulars as to the local incidence of the decline in the birth-rate. It shared, however, to the full extent in the general decline which dates there from 1871 , when the birth-rate was $28 \cdot 1$, subsequently declining to $22 \cdot 3$ in 1890 , a fall of over 20 per cent.

A French sociologist regards a birth-rate of 25 per 1,000, even from the French point of view, as the minimum compatible with social health, and a smaller rate as an index of a pathological condition, whatever the death-rate may be.

The depopulating effect of these low birth-rates is neutralized to a considerable extent by an accompanying decline in the deathrates; but it would have been more satisfactory to have been able to regard the many lives saved and prolonged by local and general sanitary measures as a clear surplus gain instead of as a partial set-off against other lives allowed to lapse. The default of 200,000 births per annum may not be considered any cause for regret in the struggle for existence, but the year 1876, from which this fall dates, marks an "epoch. If not "one of the stages on the road of the nation's history," it ushers in such an alteration in the relation between births and population as will considerably modify the nation's future, but one for which different counties and towns have been shown to have a widely-varying amount of responsibility.

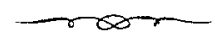

